\title{
FEATURES OF FORMATION OF PROFESSIONAL COMPETENCE OF FUTURE DOCTORS IN MODERN CONDITIONS
}

\author{
A.B. Kostyshyn ${ }^{1}$, Z.R. Ozhogan ${ }^{1}$, Z.T. Kostyshyn ${ }^{2}$, O.M. Ilnytska², V.M. Shturmak ${ }^{2}$ \\ Ivano-Frankivsk National Medical University, Ivano-Frankivsk, Ukraine: \\ ${ }^{1}$ Department of Orthopedic Dentistry, \\ ORCID ID: 0000-0001-5500-0874, \\ ORCID ID: 0000-0003-4220-2658; \\ ${ }^{2}$ Department of Dentistry of Postgraduate Education, \\ ORCID ID: 0000-0002-1840-8317, \\ ORCID ID: 0000-0002-9294-4783, \\ ORCID ID: 0000-0002-6667-3406, \\ e-mail: kostushunzorjana1907@gmail.com
}

\begin{abstract}
IFNMU actively uses educational innovations in various pedagogical processes, determining adequate mechanisms for the transformation of higher education. After all, innovative education is a constant desire to reevaluate values, preserve those that are of undeniable importance, and discard those that are already outdated.

In the practice of IFNMU, the diversification of educational technologies allows effectively combine them through the modernization of traditional education and its reorientation to distance education. With this approach, teachers focus on the personal development of future professionals, the ability to master new experiences of creative and critical thinking, finding solutions to educational problems. Therefore, we consider the innovative educational technology as a general didactic process, which consists in using a set of methods and techniques of joint activities of the subjects of the educational process aimed at achieving the goal of learning, personality development and creative and professional acquisition of knowledge and competencies in accordance with the tasks of training specialists of modern times.
\end{abstract}

The process of forming the professional competence of future doctors consists of a set of consistent, purposeful actions that contribute to the renewal, modification of purpose, content, organization, forms and methods of teaching and education, adaptation of the educational process to new socio-historical conditions. Innovations in medical education do not arise spontaneously, but arise as a result of systematic scientific research, analysis, generalization of pedagogical experience. The basis of these processes is the implementation of the achievements of psychological and pedagogical science in practice, study, generalization and dissemination of advanced domestic and foreign pedagogical experience in training doctors.

At the present stage, the integration of knowledge in pedagogical theory is seen as a synthesis of interacting sciences on the basis of some basic discipline. The mechanism of interdisciplinary integration is to implement the explanatory, constructive and prognostic functions of academic disciplines, in their transformation into a methodological, theoretical and technological means of building holistic models of the researched phenomena and processes, solving cognitive and professional problems.

As the practical experience of synchronizing the study of related educational material from different courses has shown, as well as the maximum use of multidisciplinary knowledge to study complex objects and concepts of medicine is an important condition for the effectiveness of the educational process.

Productive integration of knowledge covers such ways as solving interdisciplinary problems, performing complex practical tasks, conducting educational and research observations, conducting lectures and practical classes, applying problem situations in one discipline to classes in another.

Keywords: innovation process, professional competence, doctor.

Introduction. Ukraine's desire to integrate into the European economic and educational space has affected the main trends in the development of the medical industry. At present, medical graduates are subject to serious requirements, which are formed under the influence of the situation on the labor market and such processes as the acceleration of the pace of development of society and the saturation of the informatization of the environment.

The main purpose of modern medical education is not the passive transfer of knowledge from teachers, but the participation of students in the educational pro- cess. Teaching methods during the XX century were based on the principle: " Prepare the student theoretically", " However, this is not enough for effective treatment". As practice has shown, knowledge alone is not enough for effective treatment.

The relevance of the topic is that the educational process in a higher medical educational institution should be built on the background of modern psychological and pedagogical technologies and introduce the maximum intensification of education for students.

The aim of the research: to consider the use of innovative technologies, features of ensuring the continu- 
ity of the educational process with future doctors in quarantine measures due to the pandemic in Ukraine and identify the main advantages and disadvantages of online learning at IFNMU departments.

Research results and their discussion. The use of innovative teaching methods in the training of IFNMU students is an objective requirement of the time, at the same time one of the important conditions for quality training at the present stage. Accordingly, an integral part of the pedagogical process is the introduction of new and more advanced methods of teaching theoretical material, as well as monitoring the knowledge and skills of students in higher medical institutions. Namely, the innovation process is a generalization of complex activities for the creation, mastery, use, dissemination of innovations as tools that implement the latest technologies, techniques, methods, programs. The peculiarity of our present is a directed change of the general system of pedagogical activity, which creates conditions for the transition from one state to a fundamentally new one. Experience of creative and innovative activity of students, gained in a higher educational institution, affects the formation of the competence of the future specialist, so the perfect implementation of innovative teaching methods allows to make students open to the innovations of thinking, forms their independent opinion. In this case, the teacher performs the functions not only of planning and organization, but also motivation and control of education, knowledge acquisition.

That is why pedagogical innovation is a purposeful, consciously organized, dynamic interaction of students and teachers, in the process of which socially necessary tasks of education are solved - high-quality training of specialists.

Educational innovation includes several areas: novelty in the field of psychological and pedagogical, socio-economic and research and production research aimed at improving the quality of the educational process, which is to improve its components systems, technologies, scientific and methodological developments and legal documents.

At the same time, psychological and pedagogical novelty, which is a component of educational innovation, is characterized by a new technology of pedagogical process, which organically combines teaching, education and development of students.

Socio-economic novelty in education includes modern technologies of personality development. Computer and telecommunication methods are used for research and production.

The process of introduction of pedagogical innovations, creative search significantly depend on the moral and psychological climate in the scientific and pedagogical team, material and technical, sanitary and hygienic and aesthetic working conditions. In their organization it is important to choose a topical scientific and pedagogical topic, a clear formulation of the purpose and objectives of creative activity as the whole team and each teacher in particular, the optimal distribution and corporation of labor.

Innovation orientation is determined by the criteria of pedagogical innovations, which include: a) novelty, which allows to determine the level of originality of the experience. There are absolute, localabsolute, conditional, and subjective levels of novelty;

b) optimality, which contributes to the achievement of high results with the least amount of time of physical and mental strength of the participants of the pedagogical process;

c) effectiveness and efficiency, which means a certain stability of positive results in the activities of the teacher;

d) the possibility of creative application of new results in mass experience, which implies the suitability of the tested experience for mass implementation in educational institutions [1].

In the educational activities of IFNMU to achieve the main goal - to provide quality training specialists, most contribute to two groups of innovations:

1) the widest possible use of information technology and various equipment in the educational process (the use of multimedia and video materials, interactive information technologies, electronic learning materials, computer testing is widely introduced in the educational process);

2) methods that stimulate educational and scientific activities of students - situational tasks. They motivate students to study the material more deeply and help them to understand and acquire practical skills.

The use of these technologies allows to improve the quality of students' education, to provide a modern approach to the formation of professional competence of future professionals. Easy access and preservation of tasks greatly simplifies the time spent on their creation, editing.

Also, the use of interactive teaching methods allows in the educational process to relieve the nervous load of students, gives the opportunity to change the forms of their activities, switch attention to key issues of the lesson, promotes the development of communication skills of the future specialist. Therefore, to activate the mental activity of students and the formation of professional thinking, the teacher must learn the forms, methods of traditional and innovative methods, taking into account the levels of knowledge and skills of each student group, widely use methods to intensify and optimize the learning process, to form in future physicians motivation for training and professional self-improvement.

As a result of our research we observe the following criteria of readiness of IFNMU teachers for innovative pedagogical activity:

- awareness of the need for innovation;

- readiness for creative activity on innovations in the institution of higher education;

- confidence that efforts to innovate will bring a positive result;

- consistency of personal goals with innovation;

- readiness to overcome creative failures;

- organic combination of innovation, personal, professional and pedagogical culture;

- the level of psychological, pedagogical and methodological readiness for innovation;

- positive perception, rethinking of their past experience and its involvement in the development of innovation; - ability to professional reflection. 
Among the methods that justify themselves in the practice of educational activities IFNMU is the use of modern information technology and technical means, as well as methods that stimulate and motivate educational and scientific activities of students.

Therefore, in the study of clinical disciplines in senior courses at IFNMU use clinical analysis, "round table", discussions, debates, brainstorming in the differential diagnosis, justification of the choice of tactics and methods of treatment.

However, students have insufficient communication skills, which may result in problems of interaction between doctors and patients. Conflicts that arise between them are the result of inability to communicate, interact, violate ethics and deontology. That is why IFNMU training focuses on the end results: the acquisition by students of certain competencies necessary to provide medical care to the patient. At the same time, special attention is paid to the methods of active education and control, which are the most effective and efficient.

The main competence of the future dentist is to provide qualified care. This shows the integral competence of the doctor, namely: the ability to solve complex tasks and problems in the field of health care, in professional activities or in the educational process, in conducting research and innovation. The general and special competencies of the dentist include: the ability to establish primary contact with the patient, to divide and classify his problems, to provide primary care regardless of the severity of the disease, sex, age and other characteristics of the patient, to be able to effectively and adequately manage using available health care resources, coordinate dental care with other specialists, ensure the protection of the patient's interests and the availability of the necessary professional care. It is very important to teach future dentists a personality-oriented approach with the formation of the ability to determine the patient's preference, to advise him without restricting the right to independence and autonomy, to provide long-term and continuous monitoring, the ability to solve certain problems of the patient through the selection and evaluation of information in the collection of medical history, examination, the ability to make decisions in emergencies, to conduct early diagnosis in the early stages of the disease, rationally prescribe diagnostic and therapeutic interventions. All of these tasks are one of the main competency requirements for a dentist. Therefore, IFNMU teachers teach students a person-centered approach to communicate with the patient, which allows to responsibly direct the methods of diagnosis and treatment in the proper direction and achieve parity in relations with him.

Under normal circumstances, students study at IFNMU through the use of traditional methods, which include:

- oral examination, which allows to control students' knowledge and correct their mistakes;

- written survey, which helps to determine the level of mastering the material and provides an objective reproduction of the real knowledge of the future specialist;

- test control, which promotes impartial and fair assessment of student knowledge.
However, the spread of COVID-19 has led to significant changes in all areas of life, namely health and education. Under quarantine conditions, with limited communication between teachers and students, each higher education institution has determined how to organize the educational process, which platforms and tools to use and which forms, except distance, to implement, because all actions are aimed not only at maintaining the quality of education and providing strong knowledge, but also to preserve the health and life of both parties to the educational process [2].

Given that the process of education of future doctors should be constant, the task of each teaching staff is to find those tools of the global network that will ensure the continuity of the educational process [3].

During the period of coronavirus spread and quarantine, the use of only traditional teaching methods is insufficient. In conditions of complete or partial isolation, a combination of different teaching methods is relevant and appropriate. In the transition to distance education in IFNMU, as in all educational institutions of Ukraine, the task was to transfer the basic principles of building a practical lesson in new realities and adapt them to interactive teaching conditions [4]. Namely - distance education, which demonstrates the transition from traditional to blended or open, distance learning and is not just one of the existing forms of educational services and one of the mechanisms for implementing the profound changes taking place in the life of modern society [5].

Thanks to the Internet, this form of education gives future doctors the freedom to choose the place, time and knowledge acquisition. At the same time, distance education is not antagonistic to traditional forms of learning, but on the contrary involves active communication between teacher and student with the help of modern technologies and multimedia. Successful solution of this problem contributes to improve the quality and level of accessibility of higher education, integration of the national education system into the scientific, industrial and cultural information infrastructure of the world community.

The most important integrated tasks of any discipline of training dentists, both off-line and on-line, are:

- ensuring its real contribution to the methodological, theoretical and technological training of future doctors for professional activities;

- purposeful formation and development of skills to use scientific knowledge;

- providing motivation to study all disciplines and master the profession;

- development of creative thinking of the intellect on the basis of a holistic approach to learning [6].

Starting from March 2020, IFNMU education is conducted online, using the platform of our university website and the team work center from Microsoft Teams, as well as additional sources of communication, namely: Facebook, Instagram, Viber, Telegram. The information support is based on the use of "cloud technologies" based on Microsoft Office 365. The concept of "cloud technologies" is distributed data processing, where applications, computer resources and capacity are provided to the user as an Internet service. Under the "cloud" means data center with its own infrastructure. The main advantage of 
using "clouds" is to hide the complex infrastructure from end users, which directly ensures the availability of information and means of its processing (software). This allows users to focus on performing their functional responsibilities without thinking about the nuances of information processing technology. In addition, various means of communication were used: e-mail, chats, forums, video conferencing, blogs [7].

Our society is ambivalent about distance education, noting the "pros" and "cons". Some believe that this method is the future, others warn of the neglect and destruction of the entire education system.

The advantages of distance education include:

- free access to education (if you have the Internet);

- the ability to adapt to any situation and requirements;

- coverage of a significant audience;

- study at a convenient time and in a comfortable environment;

- the possibility of combining studying with other activities;

- use of an individual approach to each student.

The main disadvantages of distance education:

- lack of direct contact between teacher and student;

- the need for internal motivation for learning;

- the problem of identifying the student's identity;

- insufficient level of ownership of modern distance education platforms;

- lack of social interaction, so learning becomes more individual [8].

The world's telecommunications infrastructure today makes it possible to create systems of mass lifelong learning, general exchange of information, regardless of temporal and spatial zones. Students have the opportunity to communicate and receive feedback from any student, wherever he is; a complete set of reference notes and methodical recommendations necessary for studying; a collection of tasks designed for productive independent mastering of disciplines; unlimited access to the modern electronic library of our university: organized catalog of copies of scientific, educational and methodical literature.

At the same time, researchers state the fact that verbal appeals of teachers and non-verbal contacts can reduce the physical and psychological distance between them and students and lead to an increase in the level of education, using the experience of the teacher. In distance education, the student generally conducts his interaction with the materials independently, while reducing the degree of control of the teacher over the learning process. This is especially true in clinical departments, in particular for students of the dental faculty. During distance education, in the absence of practical activities of students directly at the patient's chair, thanks to the "Internet" it is possible to obtain information from webinars, master classes, demonstrations of manipulations on simulators and phantoms [9].

Therefore, the efforts of IFNMU teachers are aimed at the development of systemic integrated clinical thinking, mastery of professional skills, the ability to decide and prescribe a set of treatment and prevention measures. It is no less important to cultivate the ability to interact and partner with specialists of different profiles in order to obtain the highest results in the treatment of the patient, teamwork, deontological behavior. For the purposes of education, the acquisition of competencies based on basic cognitive, operational, legislative, communicative skills is provided, as well as the main role in the process of independent work is given to selfeducation. The competence of a dentist is formed during professional activity and characterizes the ability of a specialist to solve urgent problems that arise during professional activity.

Conclusions. In the light of current problems of the modern health care system, it becomes clear that we should not only actively seek new ways to improve the quality of education of medical students, but also more widely implement promising innovations in the structure of the educational process.

At the same time, over the past 2020, during the pandemic, distance education has actively entered our lives, despite the fact that it limits the contact between teacher and student, creating psychological discomfort and a sense of interaction only with the information system and not with a living person. If forms of study are used in which there is no direct contact and no identification of the person, then there is a problem of determining whether the student performed the task by passing the tests. Sometimes high-quality distance education is hampered by a lack of practical skills of teachers and students to work with modern distance learning platforms. Despite numerous discussions about the advantages and disadvantages of distance education and criticism from many teachers, distance education in quarantine has taken an important place in the modern education market and is quite effective in the face of global challenges and modern realities.

Given the complex realities of our time and the duration of quarantine measures, the distance education system in dental education has become an integral part of the educational process at IFNMU and continuous professional development of dentists through the dynamic introduction of educational platforms available to listeners with the widest possible use of available WEBresources.

Distance education has occupied a significant niche in providing quality education that meets the requirements of modern society. The results of the survey confirm that both students and scientific and pedagogical workers understand the need to work in forced distance conditions caused by the pandemic, with a more practical and conscious approach to overcome the existing digital barriers in the education system, and the system of vocational studying itself must correspond to modern social changes, must significantly increase its ability to innovate and respond flexibly to the needs of the labor market. Therefore, in working with interns and students, both traditional teaching methods and innovative technologies are used to form the professional competence of future doctors.

\section{References:}

1. Kostyshyn AB. Ensuring the quality of higher education under current conditions. Arkhiv klinichnoi medytsyny. 2020; 2(26):38-42.

2. Kostyshyn A. Osoblyvosti profesiinoi pidhotovky maibutnikh likariv u period pandemii. Mizhnarodna dystantsiina naukovo-praktychna konferentsiia. 
Tekhnolohii dystantsiinoho navchannia: vprovadzhennia, rozvytok, udoskonalennia; 2021; Berez, 24; Kharkiv; 2021.

3. Pavlenko OV, Volosovets TM, Doroshenko OM, Doroshenko MV, Bakshutova NO. Zastosuvannia dystantsiinoi osvity u pisliadyplomnii pidhotovtsi likariv-stomatolohiv v umovakh karantynnykh zakhodiv. Medychna osvita. 2020; (3):13-16.

4. Yeroshenko HA, Shepitko VI, Yakushko OS, Lysachenko OD. Dosvid vprovadzhennia dystantsiinoi formy navchannia na kafedri histolohii, tsytolohii ta embriolohii. Visnyk problem biolohii i medytsyny. 2020; 2(156):194-7.

5. Mekhovych SA, Minakova SM. Metody dystantsiinoi osvity - nevidiemna skladova navchalnometodychnoho kompleksu. Materialy I Vseukr. nauk.prakt. konf. «Dystantsiina osvita Ukraini: innovatsiini, normatyvno-pravovi, pedahohichni aspekty». 2020; Cherv. 16. P.89-92.

6. Lysachenko OD, Yeroshenko HA, Bilash VP, Pelypenko LB, Shevchenko KV. Dystantsiine navchannia na kafedrakh morfolohichnoho profiliu $\mathrm{v}$ umovakh karantynu. perevahy ta nedoliky. Visnyk Problem biolohii i medytsyny. 2020; 3(149):188-191.

7. Churpii IK, Golod NR, Yaniv OV, Tudosy VH, Kuravska YuS, Fedorivska LP, Kvasniuk DI. Analiz osoblyvostei dystantsiinoho navchannia ta mozhlyvist yoho povnotsinnoi intehratsii u navchalnyi protses. Art of Medicine. 2020; 4(16):135-138.

8. Baryshnikova VV, Avlasenko-Kanarovych OO. Osnovni perevahy ta nedoliky dystantsiinoi osvity. Materialy I Vseukr. nauk.-prakt. konf. «Dystantsiina osvita Ukraini: innovatsiini, normatyvno-pravovi, pedahohichni aspekty»; 2020; Cherv. 16. P.13-5.

9. Bielikov OB, Vatamaniuk NV, Struk VI. Dystantsiine navchannia yak pryntsyp vidkrytoho zaniattia. Klinichna stomatolohiia. 2020; (3):78-81.

\section{УДК 37.018.43+614.253.4 \\ ОСОБЕННОСТИ ФОРМИРОВАНИЯ ПРОФЕССИОНАЛЬНОЙ КОМПЕТЕНТНОСТИ БУДУЩИХ ВРАЧЕЙ В СОВРЕМЕННЫХ УСЛОВИЯХ}

\author{
А.Б. Костишин ${ }^{1}$, 3.Р. Ожоган ${ }^{1}$, 3.Т. Костишин ${ }^{2}$, \\ А.М. Ильницкая ${ }^{2}$, В.М. Штурмак² \\ Иван-Франковский нацииональный медицинский \\ университет, г. Ивано-Франковск, Украина, \\ ${ }^{1}$ кафедра ортопедической стоматологии, \\ ORCID ID: 0000-0001-5500-0874, \\ ORCID ID: 0000-0003-4220-2658; \\ ${ }^{2}$ кафедра стоматологии последипломного \\ образования, \\ ORCID ID: 0000-0002-1840-8317, \\ ORCID ID: 0000-0002-9294-4783, \\ ORCID ID: 0000-0002-6667-3406, \\ e-mail: kostushunzorjana1907@gmail.com
}

Резюме. В ИФНМУ активно используются образовательно-учебные инновации в различных педагогических процессах, определяя адекватные механизмы трансформации высшей школы.

Актуальность тематики заключается в том, что образовательный процесс в высшем медицинском учебном заведении максимально вводит интенсификацию обучения для студентов на фоне современных психолого-педагогических технологий.

Целью исследования было рассмотреть применение инновационных технологий, особенности обеспечения непрерывности учебного процесса с будущими врачами в условиях карантина из-за распространения коронавирусной инфекции, определить преимущества и недостатки обучения on-line на кафедрах ИФНМУ.

Результаты. В практике ИФНМУ диверсификация учебных технологий позволяет результативно сочетать их через модернизацию традиционного обучения и переориентацию его на дистанционное. При таком подходе внимание преподавателей акцентируется на личном развитии будущих специалистов, способности овладевать новым опытом творческого и критического мышления, поиска решения учебных задач.

Процесс формирования профессиональной компетентности будущих врачей состоит из совокупности последовательных, целенаправленных действий, которые способствуют обновлению, модификации цели, содержания, организации, форм и методов обучения и воспитания, адаптации учебного процесса к новым условиям. Инновации в медицинском образовании не возникают спонтанно, а являются результатом системных научных исследований, анализа, обобщения педагогического опыта.

Выводы. Основой названных нами процессов является внедрение достижений психологопедагогической науки в практику, изучение, обобщение и распространение передового отечественного и иностранного педагогического опыта подготовки врачей.

Ключевые слова: инновационный процесс, профессиональная компетентность, врач.

\section{УДК 37.018.43+614.253.4 \\ ОСОБЛИВОСТІ ФОРМУВАННЯ ПРОФЕСІЙНОӤ КОМПЕТЕНТНОСТІ МАЙБУТНІХ ЛІКАРІВ У СУЧАСНИХ УМОВАХ}

А.Б. Костишин ${ }^{1}$, 3.Р. Ожоган ${ }^{1}$, 3.Т. Костишин ${ }^{2}$, О.М. Ільницька ${ }^{2}$, В.М. Штурмак
Івано-Франківський національний медичний університет
м. Івано-Франківськ, Україна:
${ }^{1}$ кафедра ортопедичної стоматології,
ORCID ID: 0000-0001-5500-0874,
ORCID ID: 0000-0003-4220-2658;
${ }^{2}$ кафедра стоматології післядипломної освіти,
ORCID ID: 0000-0002-1840-8317,
ORCID ID: 0000-0002-9294-4783,
ORCID ID: 0000-0002-6667-3406,
e-mail: kostushunzorjana1907@gmail.com 
Резюме. В ІФНМУ активно використовуються освітньо-навчальні інновації в різних педагогічних процесах, визначаючи адекватні механізми трансформації вищої школи.

Актуальність тематики полягає в тому, що освітній процес у вищому медичному навчальному закладі максимально запроваджує інтенсифікацію навчання для студентів на тлі сучасних психологопедагогічних технологій.

Метою дослідження було розглянути застосування інноваційних технологій, особливості забезпечення безперервності навчального процесу 3 майбутніми лікарями в умовах карантину через поширення коронавірусної інфекції, визначити переваги та недоліки навчання on-line на кафедрах ІФНМУ.

Результати. У практиці ІФНМУ диверсифікація навчальних технологій дозволяє результативно ïx поєднувати через модернізацію традиційного навчання та переорієнтацію його на дистанційне. За такого підходу увага викладачів акцентується на особистому розвитку майбутніх фахівців, здатності оволо- дівати новим досвідом творчого і критичного мислення, пошуку вирішення навчальних завдань.

Процес формуванні професійної компетентності майбутніх лікарів складається 3 сукупності послідовних, цілеспрямованих дій, які сприяють оновленню, модифікації мети, змісту, організації, форм і методів навчання та виховання, адаптації навчального процесу до нових умов. Інновації в медичній освіті не виникають спонтанно, а постають результатом системних наукових пошуків, аналізу, узагальнення педагогічного досвіду.

Висновки. Основою названих нами процесів $\epsilon$ впровадження досягнень психолого-педагогічної науки в практику, вивчення, узагальнення і поширення передового вітчизняного та іноземного педагогічного досвіду підготовки лікарів.

Ключові слова: інноваційний процес, професійна компетентність, лікар.

Стаття надійшла в редакцію 01.04. 2021 р. 